2. Catarrhalis.-This, pathologico-anatomically, means the transition of a fibrous nodule into caseous masses and the formation of exudative caseous foci. As a rule the upper lobe is affected, and some degree of dullness is present with bronchial breathing and crepitation. There are complications in approximately 15 per cent. of the cases. Healing is due to the formation of fibrous tissue, which is interspersed also between the affected and sound parts of the lung. Clinically in 30 per cent. crepitation disappears, and dullness is not so distinct as before. The patient's capacity for work is about 90 per cent.

3. Fibrosa.-The pathologico-anatomical condition is the further spread of caseous masses, their liquefaction, and the formation of tuberculous ulcers. Marked dullness may be detected over the affected area with bronchial breathing and prolonged expiration. Fine moist rales and medium rales as a rule may be heard. There are complications in about 25 per cent. Healing is due to the removal of caseous masses from the bottom of the ulcer; then follows the contraction of the cavities by fibrous tissue. Clinically bronchial breathing and dullness over the affected area are always present; moist rales are absent in about 10 per cent. The capacity for work is relatively about 70 per cent.

4. Ulcerosa.-This, pathologico-anatomically, is the spreading of the process with caseous degeneration, and the coalescence of small cavities to form large ones. Over the area of small cavities there is no marked change in the dullness, but a large cavity with thick walls or surrounded by caseating lung tissue, especially when empty, will give, as a rule, a dull note of high pitch with some resonance. On auscultation a low-pitched amphoric breathing is heard, with bubbling rales, crepitations, and also resonant rales. Complications occur in about 40 per cent. of the cases. The process of healing is due to the emptying of the cavities and the contraction of their walls by fibrous tissue. Clinically, with the exception of 5 per cent., rales and very distinct amphoric breathing are usually present. The capacity for work is about 35 per cent:

\section{Secondary Forms.}

If caseous masses are not ejected from the affected area of the upper lobe they may be transferred by aspiration through bronchi and form new foci either in the lower lobe or in the neighbouring part of the lung. In this way they give rise to an exudative caseous process and to pneumonic foci.

\section{A. Broncho-pneumonia Metastatica Chronica.}

1. Fibrosa.-Pathologico-anatomically this form is due to the aspiration of caseous masses into one of the bronchi of the lower lobe. There are the same changes in the lungs as in the primary form of fibrous tuberculosis, but between the two affected areas there is a quite normal one. Complications occur in 50 per cent. of the cases, and recovery is impossible. The capacity for work is 15 per cent.

2. Ulcerosa.-The condition resembles that just described, with the exception of the character of the process, which is the same as in tuberculosis ulcerosa. The incidence of complications and the capacity for work are the same as in the foregoing.

\section{B. Pneumonia Tuberculosa Chronica.}

This form is due to coalescence of many broncho-pneumonic foci, and develops into continuous exudative caseous tuberculosis.

1. Fibrosa.-Infiltration or consolidation of nearly the whole lung, with the clinical signs previously described. Recovery is impossible. Complications occur in more than 50 per cent., and there is practically no capacity for work.

2. Ulcerosa.-Cavities may be found in all parts of the lung. The clinical signs are as previously described. Recovery is impossible. Complications are found in more than 50 per cent., and the capacity for work is practically nil.

In comparison with Turban's classification this one is exceptionally complete. Instead of Turban's third stage it gives a full account of all the progressive changes in the lungs. Turban's third stage does not indicate the condi- tion of the lungs, but from Gabrilovitch's classification the condition of the pulmonary process may be discerned without further investigation.

This classification shows not only the character of the process, but also the prospects as regards treatment and prognosis-an exceptionally important point. Broncho. pneumonia is always more dangerous than simple pneumonia; the regime in this case must be very severe, and the prognosis extremely grave. Turban's classification gives us no indication as to the nature of the process nor how it spreads. All these considerations are based not on my personal experience only, but also on statistics. If the same area is affected both by broncho-pneumonia and pneumonia, and even if the affected area in the case of pneumonia is the larger, the prognosis is always better for pneumonia than for broncho-pneumonia.

As regards statistics, Turban's "third" stage is silent, and all statistics founded on this classification give not the slightest idea about the nature of tuberculous processes and are of very little value.

The advantage of this classification has been proved statistically. In my work (with Miss Elderton) "Correlation between prognosis based on the condition of the tuberculous patient at entry to a sanatorium, and the issue" (Annals of Eugenics, Vol. II, Parts I and II, April 1927; Cambridge University Press), on page 65 we find: "There is no doubt that the three stages of the TurbanGerhardt Classification are not sufficient for prognosis, and that the subdivision of Group III by Professor Gabrilovitch's method is an improvement." And further (page 75), as a conclusion: "(2) In estimating issue from stage, the Stage III of the Turban-Gerhardt Classification shou'd be subdivided following the divisions used by Professor Gabrilovitch."

\section{COLLOIDAL ANTIMONY IN THE TREATMENT OF TUBERCULOSIS.}

PERCY MOXEY, M.B., Ch.B.,

TUBERCULOSIS OFFICER AND DEPUTY M.O.H., PORT AND BOROUGH OF SOUTHAMPTON.

In previous articles ${ }^{1}$ attention has been drawn to the treatment of tuberculosis by means of intramuscular injections of collosol antimonium (Crookes). A large number of cases have now been treated by this method, and the results obtained are given below. Cases are separated into sputum + and sputum-, and the spritum + cases are separated into groups according to the classification adopted in the Ministry of Health Memorandum 37/T.

During the latter half of 1826196 cases were placed on this treatment; 90 were sputum-, and have nearly all done very well, 3 only having died up to date, but no detailed statement will be made concerning these, as with sputum - cases the diagnosis is open to doubt, and the value of the treatment cannot therefore be demonstrated.

The sputum + cases numbered 106-11 in Group 1, 23 in Group 2, and 72 in Group 3. No case is included which did not have at least two months' treatment in 1926, and the results are as follows.

\begin{tabular}{|c|c|c|c|c|c|c|}
\hline & Quiescent. & Improved. & $\begin{array}{l}\text { Not \&o } \\
\text { Well. }\end{array}$ & Died. & $\begin{array}{l}\text { Left } \\
\text { Area }\end{array}$ & \\
\hline $\begin{array}{l}+1 \\
+2 \\
+3\end{array}$ & $\begin{array}{l}7 \\
6 \\
2\end{array}$ & $\begin{array}{r}4 \\
17 \\
56\end{array}$ & $\begin{array}{l}0 \\
0 \\
9\end{array}$ & $\begin{array}{l}0 \\
0 \\
5\end{array}$ & $\begin{array}{l}0 \\
0 \\
0\end{array}$ & $\begin{array}{l}\text { July lst, } 1927-6 \text { months or } \\
\text { more after commence- } \\
\text { ment of treatment. }\end{array}$ \\
\hline $\begin{array}{l}+1 \\
+2 \\
+3\end{array}$ & $\begin{array}{r}7 \\
13 \\
5\end{array}$ & $\begin{array}{r}3 \\
9 \\
34\end{array}$ & $\begin{array}{r}0 \\
0 \\
10\end{array}$ & $\begin{array}{r}1 \\
0 \\
19\end{array}$ & $\begin{array}{l}0 \\
1 \\
4\end{array}$ & $\begin{array}{l}\text { Jan. 1st,1928-12 months or } \\
\text { more after commence. } \\
\text { ment of treatment. }\end{array}$ \\
\hline $\begin{array}{l}+1 \\
+2 \\
+3\end{array}$ & $\begin{array}{r}7 \\
15 \\
7\end{array}$ & $\begin{array}{r}3 \\
5 \\
15\end{array}$ & $\begin{array}{r}0 \\
2 \\
13\end{array}$ & $\begin{array}{r}1 \\
0 \\
32\end{array}$ & $\begin{array}{l}0 \\
1 \\
5\end{array}$ & $\begin{array}{l}\text { At present-18 months or } \\
\text { more a ter commence- } \\
\text { ment of treatment. }\end{array}$ \\
\hline
\end{tabular}

Four deaths were from other causes, but as the tuberculosis was a contributing factor these are included in the above figures. It will be noted that 67 cases of the original 106 are still under observation or treatment. 
Of the cases coming under treatment in the first half of 1927 the following is the result.

\begin{tabular}{|c|c|c|c|c|c|c|}
\hline & Quiescent. & Improted. & $\begin{array}{l}\text { Not so } \\
\text { Well. }\end{array}$ & Died. & $\begin{array}{l}\text { Left } \\
\text { Area. }\end{array}$ & \\
\hline $\begin{array}{l}+1 \\
+2 \\
+3\end{array}$ & $\begin{array}{l}4 \\
2 \\
1\end{array}$ & $\begin{array}{l}12 \\
15 \\
26\end{array}$ & $\overline{1}$ & $\overline{1}$ & $\bar{z}$ & $\begin{array}{l}\text { Jan. 1st, } 1928-6 \text { months or } \\
\text { more after commence- } \\
\text { ment of treatinent. }\end{array}$ \\
\hline $\begin{array}{l}+1 \\
+4 \\
+3\end{array}$ & $\begin{array}{l}9 \\
6 \\
0\end{array}$ & $\begin{array}{r}5 \\
7 \\
12\end{array}$ & $\begin{array}{l}1 \\
4 \\
5\end{array}$ & $\begin{array}{r}1 \\
1 \\
18\end{array}$ & $\overline{1}$ & $\begin{array}{l}\text { At present-12 months or } \\
\text { more after commence- } \\
\text { ment of treatment. }\end{array}$ \\
\hline
\end{tabular}

Every case, however severe, is placed on this treatment, and when it is remembered that patients attending municipal clinics come mostly from the poorest section of the community-unsuitably housed, overcrowded, often ill nourished-then 1 think that the results will compare favourably with those obtained by other methods. With selection of cases for treatment the results would be much better.

Very little change has been made in the method of treatment given in previous articles, except that the collosol antimonium has been increased up to $2 \mathrm{c.cm}$. twice weekly, and in cases where the muscle will not tolerate this amount it is given intravenously. So far I have found no contraindications to the use of antimony, and with some 30,000 injections there has been no worse result than a swollen and slightly painful arm.

The present article deals mainly with the results obtained by the use of colloidal antimony, but good results cannot be expected without the usual rest, fresh air, good food, and other measures which are generally accepted as essential to the treatment of all cases of pulmonary tuberculosis.

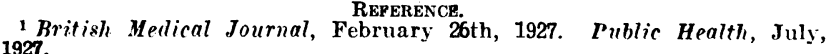
1927.

\section{fftemoranda:}

\section{MEDICAL, SURGICAL, OBSTETRICAL.}

THE PAPILLAE FOLIATAE AND CARCINOPHOBIA. THE papillae foliatae are a row of small vertical projections of mucosa on the side of the tongue inmediately anterior to the attachment of the palatoglossal folds. Wholly restigial in human beings, they contain a few taste buds, and represent much larger structures such as are seen in the rabbit. It would seem that but little pathological significance could be ascribed to them, yet during the past few years they have quite frequently come under my attention in two types of circumstances.

In the commoner type they are in no way diseased, but they have caused grare worry to the patient, who, both mentally and physically introspective, has discovered at the side of the tongue these warty structures, alongside which as a rule a few largish veins are crident. It is characteristic of these cases that the tongue can be protruded almost for its whole extent from the mouth. It should at once be recognized that the sole duty then of the medical practitioner is to make the emphatic statement, "You have not a cancer"; with very few exceptions this utterance is rewarded by a look of intense contentment. In some instances, however, they are inflamedoedematous and swollen-and are causing pain. The infection is from an adjacent molar tooth or tonsillar crypt (the pain sometimes is probably referred along the lingual nerve); treatment is obvious. C. Jennings Marshall, M.S., F.R.C.S.,
Assistant Surgeon, Charing Cross Hospital.

\section{OVERLOOKED ALVEOLAR ABSCESS.}

Is riew of the renewed interest in the effect of dental conditions on the general health I think it worth while recording two cases of a condition more obvious than infected pulpless teeth. Such ceses are not rare in dental practice, but in riew of the prolonged medical treatment that was given ineffectively they may help to direct attention to them at this time.

(1) A girl, aged 13, had noticed pain and swelling on the left for more than twelve months. Examination revealed the presence of two diseased roots of the lower left first moiar tooth, the crown having broken off. The gums were chronically inflamed from the irritation, but no obvious signs of pus were visible in the mouth. Externally there was an indurated swelling with a into the body of the mandible. The carious roots were extracted, and were found to be surrounded by a mass of granulation tissue and a found to be surrounded by a mass of granulation tissue scribed, and at two subsequent visits the socket was examined, scribed, and at two subsequent visits the socket was examined,
and syringed once. Two months later the sinus had completely healed up, and a year later appeared quite healthy. The scar was still visible.

(2) A girl, aged 17, had noticed fifteen months previously a swelling of the lower left jaw region, associated with much pain and tenderness, for which various remedies were tried. She was pale and anaemic, with almost a chlorotic tinge of the skin. On the left side of the mandible was a raised red area, two inches long and $3 / 4$ in. wide; it was indurated and painful on the slightest touch, and pus oozed from a sinus. In the mouth a carious lower left first molar tooth was surrounded by highly inflamed gingival tissue and three pea-like swellings containing pus. The gingival tissue and three pea-like swellings containing pus. The
breath was fetid, and the whole mouth had an offensive odour. On extracting the tooth foul-smelling pus welled up, and the roots were very offensive. Pus was expressed and the socket and sinus were thoroughly syringed. The usual treatment at home was prescribed, and within two weeks improvement was observable. Two months later the patient's general health and digestion were much better, and the swelling and sinus had almost completely healed.

Both these patients had been under treatment for more than a year with no apparent improvement; in the second case, the general health was getting worse, in spite of ultra-riolet ray treatment, among other remedies adopted. The most effective treatment for such cases appears to be extraction of the tooth as early as possible, since this nearly always has to be performed eventually, before the condition can be cured. It is, of course, regrettable that teeth, especially children's, should erer get to this stage, when proper dental treatment of early caries car usually save them.

\section{G. Graham Macphee, M.B., Ch.B., L.D.S.Glas.}

DUPLICATION OF THE TESTICLE.

Wirt reference to the interesting account by $\mathrm{Mr}$. Edington on Jume 2nd (p. 937) of a case of duplication or subdivision of the testicle, the following details of another case encountered a few days after the publication of Mr. Edington's article may be worthy of record.

A boy, aged 6, was admitted to the North Staffordshire Royal Infirmary with a diagnosis of double inguinal hernia associated with double undescended testicles. On examination the right testicle was felt high up, just outside the external abdominal ring. It was smaller tiran normal in size and could be brought down easily into the scrotum. The ring was slightly enlarged and a definite impulse was obtained when the patient coughed. On the left side no testicle could be palpated and no hernia was demonstrable. A condition of penile hypospadias was present.

operation.-The right external ring was exposed. A congenital sac was found, at the lower end of which was present a small testicle with a well-formed epididymis and vas; this was the testicle palpable before operation. A bout $1 \frac{1}{2}$ in. higher up the sac a second body, exactly similar in size and shape, was present; it had a well-formed epididymis and vas. No communication between the two swellings was apparent. The two vasa did not measured $1.25 \mathrm{~cm}$. in length and $0.5 \mathrm{~cm}$. in breadth. The testes the sac was tied and divided, and the distal portion of the sac was left in situ. In view of the failure to demonstrate any wasticle on the left side, it was considered desirable to leave both testicles on the right side.

This case would seem to come into class " $\mathrm{B}$ " in $\mathbf{M r}$. Edington's group-namely, pseudo-duplication or transverse ectopia; it is of interest to note its association with hypospadias

I am indebted to Mr. Hartles for permission to record the case. stoke-on-Trent. JohN S. Ramage, M.B., F.R.C.S.E.

\section{TRAUMATIC RUP'TURE OF TUBERCULOUS ILEO-CAECAL GLANDS.}

RUPTURE by violence of tuberculous mesenteric glands is perhaps sufficiently rare to render the following clinical details worthy of record.

A child, aged 5 years, was brought to hospital with the story hat she had been playing on her sister's back some three hours previously, when she had fallen off and her sister had fallen on top of her. The child had at once cried out in pain, and shortly afterwards had vomited.

I found the child suffering severely from shock; she had a weak thready pulse of 156 , and a temperature of $101.4^{\circ} \mathrm{F}$. She complained of pain all over the abdomen and the legs were drawn up; the abdomen moved very slightly on respiration and was almost board-like in its rigidity, and very tender on palpation. 